\title{
INTEREST RATE DAN POLITICAL CONNECTION PADA HARGA SAHAM
}

\author{
Putri dan Farah Margaretha Leon \\ Fakultas Ekonomi dan Bisnis \\ Universitas Trisakti \\ farahmargaretha@trisakti.ac.id
}

Diterima 26 Juli 2018, Disetujui 31 Juli 2018

\begin{abstract}
Abstrak
Latar Belakang Penelitian berkaitan dengan harga saham yang dijadikan indikator dalam pengukuran kondisi keuangan sebuah perusahaan dalam membuat keputusan dalam berinvestasi. Oleh karena investor perlu mengetahui apa saja faktor yang dapat mempengaruhi harga saham sebuah perusahaan tersebut. Tujuan Penelitian ini adalah untuk mendapatkan bukti empiris mengenai faktor yang mempengaruhi harga saham dengan menggunakan suku bunga dan hubungan politik sebagai variabel moderasi. Metode Penelitian yang digunakan adalah regresi berganda. Populasi pada penelitian ini adalah seluruh perusahaan yang konsisten terdaftar di BEI selama periode 2012 sampai tahun 2016. Teknik pengambilan sampel dalam penelitian ini menggunakan teknik pengambilan sampel dengan sengaja. Ada 63 perusahaan terpilih yang dijadikan sampel. Hasil penelitian menunjukkan bahwa dividen, laba per lembar saham (EPS), penghasilan atas modal (ROE) dan laba setelah pajak (PAT) secara parsial mempengaruhi harga saham. Namun di sisi lain rasio retensi (RR) tidak mempengaruhi harga saham dari sebuah perusahaan. Variabel moderasi suku bunga memiliki efek moderasi pada dividen, ROE dan PAT, namun tidak ada efek moderasi pada RR dan EPS. Variabel moderator hubungan politik memiliki efek moderasi pada EPS dan PAT namun tidak memiliki efek moderasi pada dividen, RR dan ROE. Implikasi Bagi Manajerial diharapkan hasil penelitian ini dapat memberikan informasi bagi manajer bahwa dividen tidak selalu berpengaruh positif pada harga saham perusahaan. Jika perusahaan ingin meningkatkan harga sahamnya, maka dianjurkan untuk memperhatikan EPS, ROE dan PAT karena ketiga variabel tersebut ditemukan berpengaruh positif terhadap harga saham.
\end{abstract}

Kata Kunci : dividen, harga saham, hubungan politik, laba per lembar saham, suku bunga, rasio retensi.

\section{Abstract}

Background of Research related with share price as indicator in assessing firm's financial condition. So that investors need to know which factors affecting share price of a company. Purpose of Research is to obtain empirical evidence about factors affecting share price with interest rate and political connection as moderating variables. Research Method adopted in this research is multiple regressions. Population in this study is companies which consistently listed in Indonesia Stock Exchange from 2012 until 2016. Technique use for taking sample is purposive sampling. There are 63 companies selected as final sample. Result Obtained shows that dividend, earnings per share (EPS), return on equity (ROE) and profit after tax (PAT) partially affected share price of a company. On the other hand, retention ratio did not affect share price of a company. Interest rate as moderating variable has moderation effect to dividend, ROE and PAT but no moderate effect found with RR and EPS. Political Connection as second moderating variable has moderation effect to EPS and PAT but did not has moderate effect to dividend, RR and ROE. Managerial Implication hopefully this research could give information for managers that dividend not always give positive impact to share price. If a company wants to increase their share price, they should pay attention to amount declared as EPS, ROE and PAT because these three variables give positive impact to share price of a company.

Keywords: dividends, share prices, political relations, earnings per share, interest rates, retention ratio. 


\section{PENDAHULUAN}

Pada umumnya tujuan perusahaan selain untuk memaksimalkan laba yang diterima melalui penjualan atau kegiatan operasi yang dijalankan, di sisi lain juga untuk meningkatkan nilai perusahaan dalam rangka mensejahterakan pemilik perusahaan atau para pemegang saham. Seperti yang dikatakan Brigham dan Houston (2011), tujuan perusahaan adalah untuk memaksimalkan nilai pemegang saham. Perusahaan yang sukses dalam menjalankan kegiatan operasinya akan dapat menghasilkan laba yang nantinya akan digunakan kembali baik untuk berinvestasi ataupun disalurkan ke para pemegang saham dalam bentuk dividen.

Investasi melaui pembelian saham merupakan salah satu contoh kegiatan investasi yang umum dilakukan bagi investor. Untuk membuat keputusan dalam berinvestasi pada sebuah saham perusahaan biasanya investor menggunakan harga saham sebagai indikator pengukurannya. Jumlah dividen yang dibagikan perusahaan juga menjadi bagian penting dari pembelian saham oleh investor. Pembayaran dividen dianggap dapat memberikan indikasi kepada masyarakat bahwa perusahaan mengikuti praktek tata kelola perusahaan yang baik (Jo dan Pan, 2009). Harga saham sebuah perusahaan tidak hanya dipengaruhi oleh pembayaran dividen yang dilakukan oleh perusahaan terkait, namun ada juga beberapa faktor lain yang bisa mempengaruhi diantaranya rasio keuangan seperti retention ratio (RR), profit after tax (PAT), earnings per share (EPS), return on equity (ROE) dan sebagainya. Rasio keuangan merupakan sumber informasi penting yang diperoleh investor mengenai kondisi perusahaan. Seperti yang dikatakan Weygandt et al (2014), investor menggunakan informasi akuntansi untuk membuat keputusan dalam membeli, menahan atau menjual kepemilikan saham sebuah perusahaan.

Selain rasio keuangan yang bisa mempengaruhi harga saham, faktor lain dari luar perusahaan juga dapat mempengaruhi harga saham di pasar. Harga saham yang selalu berfluktuatif di pasaran disebabkan karena beragamnya informasi yang sedang beredar di masyarakat umum. Peristiwa peristiwa tertentu yang sedang booming baik di tingkat nasional maupun internasional turut mempengaruhi keadaan perekonomian di suatu negara. Hal ini juga patut untuk dipertimbangkan mengingat segala informasi yang diterima investor dapat mempengaruhi keputusan mereka dalam berinvestasi.
Peristiwa politik memang tidak mengintervensi bursa saham secara langsung, namun peristiwa ini merupakan salah satu informasi yang diserap oleh pelaku pasar modal dan digunakan untuk memperoleh keuntungan yang diharapkan di masa yang akan datang (Trisnawati, 2011). Kondisi politik tersebut menggambarkan bagaimana tingkat kestabilan perekonomian di suatu wilayah karena merupakan suatu hal yang penting bagi investor untuk memikirkan kelangsungan investasinya dalam jangka panjang. Misalnya saja peristiwa yang baru saja terjadi dan masih hangat untuk di dengar, pemilihan kepala daerah DKI Jakarta yang dilakukan pada Februari lalu. Penyelenggaraan Pilkada DKI Jakarta 2017 bisa saja membuat para investor memutuskan untuk menunda mengivestasikan dana investasinya di Jakarta. Hal tersebut didorong oleh kekhawatiran para investor terhadap perubahan kebijakan di sektor ekonomi dan bisnis bila terjadi pergantian pemimpin. Apabila ketertarikan investor menurun terhadap investasi pembelian saham, maka harga saham perusahaan pun melemah karena sedikit peminatnya. Hal ini berkaitan dengan teori permintaan. Makin banyak yang tertarik untuk melakukan pembelian atas saham tertentu, maka mampu menaikkan harga saham tersebut, begitu pula sebaliknya.

Selain kondisi politik, tingkat suku bunga juga mampu mempengaruhi harga saham perusahaan. Di saat perusahaan akan go public, perusahaan menjual saham untuk meningkatkan modal. Investor yang tertarik akan membeli saham ini dan mengharapkan pembagian dividen serta kenaikan nilai saham di masa depan. Apabila suku bunga yang berlaku lebih tinggi, permintaan untuk investasi akan berkurang. Hal ini terjadi karena pada saat tingkat suku bunga meningkat, masyarakat akan menarik uang mereka dari pasar modal dan lebih memilih menyimpannya di bank (Barakat et al, 2016). Hal ini mengakibatkan menurunnya permintaan akan saham di pasar karena investor meyakini bahwa pengembalian dengan persentase tertentu pada investasi saham bukan merupakan hal yang pasti jika dibandingkan dengan persentase yang dijanjikan oleh pihak bank atas deposito yang disetorkan oleh pemilik dana. Harga saham yang kian menurun akan berdampak pada penurunan nilai perusahaan pula. Jika hal ini terjadi, perusahaan akan mengalami kesulitan untuk menarik hati investor untuk menanamkan sahamnya diperusahaan tersebut. Kelangsungan hidup perusahaan menjadi terancam dan akan timbul masalah pendanaan, perlunya biaya lebih utuk memperoleh modal tambahan, dan sebagainya. 
Bagi perusahaan yang dalam jajaran Board of Directors (BOD) nya memiliki hubungan politik mungkin dapat memberikan keuntungan dalam memperoleh dana tambahan dari pihak luar. Berdasarkan uraian yang telah disebutkan sebelumnya, analisis mengenai faktor yang dapat mempengaruhi harga saham baik dari rasio keuangan dan faktor eksternal perusahaan patut menjadi perhatian bagi pihak manajemen untuk menghindari hal yang tidak diinginkan terjadi dalam perusahaan.

Tujuan umum yang ingin dicapai dari penelitian ini adalah untuk mengetahui faktor yang mempengaruhi harga saham dengan interest rate dan political connection sebagai moderating variable pada perusahaan yang terdaftar di BEI periode tahun 2012 sampai dengan tahun 2016.

\section{KAJIAN TEORI}

Penelitian mengenai dividen dan EPS yang dilakukan di Jordan. Penelitian ini meneliti tentang cash dividends, retained earnings and stock prices: evidence from Jordan (Wasfi Al Troudi dan Milhem, 2013). Sampel perusahaan ini adalah semua perusahaan yang tercatat di Amman Stock Exchange pada tahun 2005 sampai tahun 2010. Hasil penelitian ini menunjukkan bahwa cash dividend dan EPS berpengaruh secara positif terhadap harga saham.

Penelitian berikutnya meneliti tentang pengaruh rasio profitabilitas, dividend per share (DPS), EPS, dan ROE terhadap harga saham perusahaan manufaktur di BEI tahun 2009 sampai tahun 2013 (Atmojo et al, 2016). Hasil penelitian menunjukkan bahwa ROA, DPS dan EPS berpengaruh secara positif terhadap harga saham. Namun untuk variabel ROE berpengaruh secara negatif terhadap harga saham.

Penelitian tentang dampak pembayaran dividen terhadap kesejahteraan pemegang saham dengan menggunakan sampel perusahaan kimia di India dengan periode tahun 1996-1997 dan 2005-2006 dilakukan oleh De Wet dan Mpinda (2013). Hasil penelitian menunjukkan bahwa dividen berhubungan secara positif terhadap harga saham yang menjadi pengukuran atas kesejahteraan pemegang saham.

Penelitian selanjutnya mengenai dampak dari kebijakan dividen pada kesejahteraan pemegang saham dengan menggunakan sampel sepuluh perusahaan terbaik dalam sektor perhotelan dan perjalanan dilakukan oleh Kumaresan (2014). Hasil penelitian menunjukkan bahwa ada pengaruh positif antara DPS, ROE dan dividend payout ratio terhadap harga saham. Sedangkan retention ratio memiliki pengaruh negatif terhadap harga saham.

Hasil penelitian yang menunjukkan retention ratio memiliki pengaruh negatif terhadap harga saham sebuah perusahaan juga dilakukan oleh Iftikhar et al (2017). Penelitian ini meneliti tentang impact of dividend policy on stock prices of firm dengan menggunakan sampel perusahaan perbankan yang terdaftar di Karachi Stock Exchange dari tahun 2005-2014.

Penelitian mengenai analisis faktor yang mempengaruhi harga saham dilakukan di Bahrain oleh Sharif et al (2015). Penelitian dilakukan dengan sampel perusahaan yang terdaftar di Bahrain Stock Exchange selama tahun 2006-2010. Hasil penelitian menunjukkan bahwa ROE, book value per share (BVS), DPS, price earnings, dan firm size secara positif mempengaruhi harga saham.

Penelitian mengenai kebijakan dividen terhadap harga saham di Oman dilakukan oleh Bilal dan Jamil (2015). Sampel yang diteliti dalam penelitian ini adalah perusahaan dalam sektor industri yang terdaftar di Muscat Securities Market (MSM) selama tahun 2009 sampai tahun 2013. Hasil penelitian menunjukkan adanya pengaruh positif antara EPS dan ROE terhadap harga saham. Namun untuk variabel profit after tax dan retention ratio tidak memiliki pengaruh terhadap harga saham.

Efek dari gelembung dividen pada harga saham di Pakistan dilakukan Iqbal et al (2014). Penelitian ini menggunakan sampel perusahaan yang masuk dalam Karachi Stock Exchange selama tahun 2002 sampai tahun 2012. Hasil penelitian menunjukkan bahwa semua variabel (retention ratio, ROE, profitability ratio, dividend payout dan ROE) memiliki pengaruh positif terhadap harga saham kecuali dividend yield dan price earnings ratio yang memiliki pengaruh negatif terhadap harga saham.

Penelitian mengenai volatilitas harga saham dan peran kebijakan dividen di Pakistan dengan sampel perusahaan yang terdaftar di Karachi Stock Exchange dilakukan Shah dan Noreen (2016). Dari hasil penelitian ditemukan bahwa EPS berhubungan positif terhadap harga saham.

Penelitian mengenai efek kebijakan dividen pada harga saham di Pakistan dilakukan oleh Ali et al (2015). Penelitian ini menggunakan sampel perusahaan non keuangan yang terdaftar di KSE100 yang menghasilkan laba dan membayar dividen dari tahun 2001 sampai tahun 2012. Hasil penelitian menunjukkan bahwa dividend payout ratio, EPS dan ROE yang memiliki pengaruh positif terhadap 
harga saham. Sedangkan dividend per share,retention ratio dan profit after tax tidak berpengaruh terhadap harga saham.

Penelitian mengenai dampak kebijakan dividen, EPS, ROE dan PAT pada harga saham perusahaan non keuangan dilakukan di Pakistan oleh Hunjra et al (2014). Hasil penelitian menunjukan bahwa dividend yield berpengaruh secara negatif terhadap harga saham dan dividend payout ratio, PAT dan EPS berhubungan positif terhadap harga saham. Untuk variabel ROE ditemukan tidak ada pengaruhnya terhadap harga saham.

Kebijakan dividen dan dampaknya terhadap harga saham pada bank komersil di Bangladesh dilakukan oleh Al Masum (2014). Penelitian ini menggunakan sampel perusahaan dalam sektor perbankan yang terdaftar di Dhaka Stock Exchange selama periode 2007 sampai tahun 2011. Hasil penelitian menyebutkan bahwa profit after tax memiliki pengaruh secara negatif terhadap harga saham.

Penelitian mengenai dampak dari variabel makroekonomi pada harga saham dilakukan Barakat et al (2016) di Mesir. Hasil pelitian menemukan bahwa interest rate, exchange rate, CPI Cosumer Price Index, dan Money Supply memiliki pengaruh terhadap harga pasar dalam jangka panjang baik di Mesir ataupun Tunisia.

Penelitian di Pakistan mengenai dampak suku bunga pada harga saham dilakukan oleh Ali (2014). Sampel penelitian mengambil perusahaan yang sahamnya ada di pasar saham Pakistan selama tahun 2004 sampai tahun 2013. Hasil penelitian menemukan bahwa suku bunga memiliki pengaruh negatif pada harga saham.

Dampak variabel makroekonomi pada harga saham pada idustri kimia dilakukan oleh Sadaf(2013). Penelitian ini menggunakan sampel perusahaan yang berada di industri kimia dan terdaftar di Karachi Stock Exchange selama periode tahun 2002 sampai tahun 2009. Hasil penelitian menemukan bahwa suku bunga tidak berpegaruh terhadap harga saham namun tingkat inflasi mempengaruhi harga saham secara negatif.

Penelitian selanjutnya mengenai struktur kepemilikan, hubungan politik dan kinerja perusahaan di Indonesia oleh Rusmin et al (2012). Penelitian ini menggunakan sampel perusahaan non keuangan yang terdaftar di BEI dari tahun 2006 sampai tahun 2009. Hasil penelitian menunjukkan bahwa political connected firms memiliki pengaruh positif terhadap EPS perusahaan.

Penelitian yang sama mengenai hubungan politik dan kinerja perusahaan juga dilakukan oleh Ang etal(2011) dengan menggunakan sampel dari perusahaan yang terdaftar di Securities Data Corporation selama tahun 1998 sampai tahun 2006. Hasil penelitian menemukan bahwa perusahaan yang memiliki koneksi secara politik akan mendapatkan manfaat dalam memperoleh akses pendanaan dari luar, potongan pajak yang lebih rendah dan kekuatan pasar yang lebih kuat.

Penelitian serupa mengenai hubungan politik dan nilai perusahaan dilakukan oleh Do et al (2009). Penelitian ini mengambil sampel dengan menggunakan data dari beberapa sumber termasuk data dari pemilihan gubernur yang dihasilkan dari website Federal Election Committee (FEC). Hasil penelitian menunjukkan bahwa perusahaan yang memiliki political connection mampu meningkatkan nilai perusahaan.

Analisis pengaruh hubungan politik dan struktur kepemilikan terhadap kinerja perusahaan dilakukan oleh Wulandari dan Raharja (2013) pada perusahaan yang terdaftar di Bursa Efek Jakarta selama periode tahun 2009 sampai tahun 2011. Hasil penelitian menunjukkan bahwa kinerja perusahaan yang memiliki hubungan politik lebih rendah dibandingkan perusahaan yang tidak memiliki hubungan politik.

Sebelum melakukan investasi, investor perlu memiliki sejumlah informasi yang berkaitan dengan dinamika return saham agar dapat mengambil keputusan tentang saham perusahaan mana yang layak untuk dipilih (Atmojo et al, 2016). Informasi yang diperoleh investor pun terkadang belum tentu menggambarkan kondisi perusahaan yang sebenarnya. Menurut Gitman dan Zutter (2015), signalling theory mengandung informasi dari dividen terhadap laba perusahaan di masa depan, dengan kata lain investor akan melihat perubahan pergerakan peningkatan atau penurunan dividen sebagai isyarat (signal) akan prospek laba perusahaan di masa depan. Salah satu hal yang menjadi fokus investor adalah pada kinerja keuangan perusahaan. Menurut investor, kinerja keuangan merupakan salah satu indikator penting untuk melihat prospek keuangan di masa yang akan datang. Semakin baik kinerja keuangan sebuah perusahaan maka akan berpengaruh baik pula pada harga saham perusahaan tersebut.

Pada umumnya, nilai dari perusahaan yang sudah go public biasanya dapat terlihat dari harga sahamnya (Asif et al, 2016). Semakin tinggi cash dividend yang dibagikan pada tahun tertentu maka semakin tinggi pula closing price harga saham perusahaan tersebut (WasfiAlTroudi dan Milhem, 
2012). Untuk menentukan kesejahteraan daripemegang saham, Kumaresan (2014) berpendapat bahwa ROE dapat dijadikan salah satu faktor penentunya. Apabila sebuah perusahaan memiliki nilai ROE yang tinggi, maka kemungkinan perusahaan tersebut akan membayarkan dividen lebih tinggi dan sebaliknya. Indikator lain yang dijadikan pertimbangan oleh investor dalam melakukan investasinya adalah nilai EPS dan profit after tax sebuah perusahaan yang dapat dilihat dari laporan keuangannya. Nilai EPS dan PAT menjadi fokus dari investor karena nilainya yang menggambarkan berapa jumlah pendapatan investor yang diperoleh sebagai dividen atas saham yang dimilikinya (Dewi dan Wahyudi, 2012). Rasio lain yang juga dilihat oleh investor adalah retention ratio. Retention ratio juga menjadi perhatian karena menurut Kumaresan (2014), jika nilai retention ratio perusahaan tinggi, maka akan mengurangi kesejahteraan pemegang saham yang menginginkan pendapatan jangka pendek berupa dividen. Hal ini terjadi karena laba yang diperoleh perusahaan tidak semua dialokasikan untuk pembayaran dividen melainkan ditanamkan kembali ke dalam perusahaan.
Selain informasi dari informasi akuntansi atau rasio keuangan, faktor dari luar perusahaan juga perlu dipertimbangkan karena turut mempengaruhi pergerakan harga saham di pasaran. Sebagai contoh nilai tingkat bunga dan kondisi politik nasional. Apabila tingkat bunga dipasaran berubah, hal ini dapat menyebabkan terjadinya fluktuasi harga saham di pasar modal yang dikarenakan adanya perubahan minat dari investor dalam merespon tingkat bunga yang berlaku di suatu waktu tertentu (Ali, 2014). Apabila minat terhadap saham menurun, dapat berakibat menurunnya harga saham perusahaan bersangkutan. Hal ini dapat membahayakan kondisi perusahaan karena perolehan dana dari pihak luar akan berkurang. Dalam kasus seperti ini, menurut Faccio (2006), perlunya perusahaan memiliki hubungan politik untuk membantu memudahkan akses dalam memperoleh pendananaan tambahan baik melalui hutang ataupun penurunan pajak dan juga membuka kesempatan untuk menguatkan posisi perusahaan di pasar.

Berdasarkan uraian yang dijelaskan di atas, berikut model penelitian yang akan digunakan dalam penelitian ini.

\begin{tabular}{|c|}
\hline Faktor Penentu Harga Saham \\
\hline Dividen \\
Retention Ratio \\
Earnings per share \\
Return on equity \\
Profit after tax \\
\hline
\end{tabular}

Variabel Independen



Variabel Moderator
Variabel Dependen

\section{Gambar 1}

\section{Kerangka Konseptual}

\section{Perumusan Hipotesis.}

\section{Pengaruh Dividen terhadap Harga Saham}

Penelitian yang dilakukan oleh Majanga (2015) memberikan hasil bahwa ada hubungan positif antara dividen dengan harga saham. Sejalan dengan penelitian Bilal dan Jamil (2015) yang menemukan bahwa dividen per lembar saham berpengaruh secara positif terhadap harga saham sebuah perusahaan. Jika sebuah perusahaan memberikan dividen yang meningkat kepada investor, akan menyebabkan harga saham ikut meningkat pula, karena berkaitan dengan teori permintaan. Begitu pula menurut Khan (2012) melaui penelitiannya menemukan bahwa ada pengaruh positif dari dividen yang dibagikan perusahaan terhadap harga saham. Berdasarkan hasil penelitian sebelumnya, dapat ditarik rumusan hipotesis untuk hubungan antara dividen terhadap harga saham, yaitu:

$\mathrm{H}_{1}$ : $\quad$ Dividen berpengaruh terhadap harga saham

\section{Pengaruh Retention Ratio (RR) terhadap Harga Saham}

Untuk retention ration, menurut Iftikhar et al (2017) menemukan adanya pengaruh negatif antara retention ratio terhadap harga saham perusahaan. Begitu pula penelitian dari Kumaresan (2014) yang menemukan bahwa retention ratio berpengaruh secara negatif terhadap harga saham. Hasil berbeda 
diperoleh oleh penelitian yang dilakukan oleh Resto dan Ravi(2015) tentang efek dividen pada stock prices. Dalam penelitiannya ditemukan bahwa retention ratio memiliki pengaruh positif terhadap harga saham perusahaan. Sehingga rumusan hipotesis untuk hubungan antara stock dividend terhadap harga saham yaitu:

$\mathrm{H}_{2}$ : Retention ratio berpengaruh terhadap harga saham

\section{Pengaruh Earnings per Share (EPS) terhadap Harga Saham}

Penelitian dari Shah dan Noreen (2016) menemukan bahwa EPS mempengaruhi harga saham secara positif. Hasil penelitian ini sejalan dengan hasil yang diperoleh Matthew et al (2014) yang menyatakan bahwa EPS berpengaruh positif terhadap harga saham. Mereka menyatakan bahwa pemegang saham menilai sebuah perusahaan di posisi lebih tinggi dengan melihat nilai EPS nya. Penelitian dari Adesola dan Okwong (2009) juga memberikan hasil serupa bahwa EPS memiliki pengaruh positif terhadap harga saham. Sehingga dapat ditarik rumusan untuk hubungan antara EPS dengan harga saham yaitu:

$\mathrm{H}_{3}$ : Earnings per share berpengaruh terhadap harga saham

\section{Pengaruh Return on Equity (ROE) terhadap Harga Saham}

Hasil penelitian dari Sharif et al (2015) memberikan hasil bahwa ROE sebuah perusahaan berpengaruh positif terhadap harga saham perusahaan tersebut. Hasil serupa yang menyatakan ROE memiliki pengaruh positif terhadap harga saham juga diperoleh oleh penelitian yang dilakukan oleh Marlina dan Clara (2016). Bilal dan Jamil (2015) juga memperoleh hasil yang sama pada penelitiannya mengenai kebijakan dividen pada harga saham, dimana ROE yang menjadi salah satu variabel independennya memiliki pengaruh positif pada harga saham sebuah perusahaan. Berdasarkan uraian tersebut dapat diperoleh rumusan mengenai hubungan antara ROE dengan harga saham yaitu: $\mathrm{H}_{4}$ : Return on equity berpengaruh terhadap harga saham

\section{Pengaruh Profit After Tax (PAT) terhadap Harga Saham}

Laba setelah pajak mempengaruhi harga saham sebuah perusahaan (Mudlofir dan Supriyanto, 2016). Hal ini beralasan karena yang menjadi perhatian utama dari pemegang saham mengenai kesuskesan sebuah perusahaan dilihat dari laba yang dihasilkan. Hasil yang sama juga diperoleh oleh Khan (2012) yang melakukan penelitian di Pakistan. Berbeda dengan penelitian Al Masum (2014) yang menyatakan bahwa PAT memiliki pengaruh negatif terhadap harga saham. Dari uraian tersebut bisa diperoleh rumusan hipotesis untuk hubungan antara profit after tax dengan harga saham yakni:

$\mathrm{H}_{5}$ : Profit after tax berpengaruh terhadap harga saham

\section{Pengaruh Interest Rate (IR) sebagai variabel} moderator terhadap Harga Saham

Menurut Ali (2014) yang melakukan penelitian mengenai dampak interest rate terhadap harga saham menemukan bahwa interest rate berpengaruh secara negatif pada harga saham. Hasil serupa diperoleh dari penelitian Barakat et al (2016) yang mengungkapkan bahwa interest rate mempengaruhi secara negatif harga saham sebuah perusahaan. Hal ini dikarenakan, fluktuasi tingkat bunga pasti akan mempengaruhi harga saham di pasaran pada umumnya. Sadaf(2013) yang juga meneliti pengaruh interest rate sebagai variabel makroekonomi juga memperoleh hasil serupa yakni interest rate memiliki pengaruh negatif pada harga saham. Dengan demikian dapat ditarik rumusan untuk hipotesis hubungan antara interest rate dengan harga saham sebagai berikut:

$\mathrm{H}_{6 \mathrm{a}}$ : Interest rate memiliki efek moderasi pada hubungan antara dividen terhadap harga saham

$\mathrm{H}_{6 \mathrm{~b}}$ : Interest rate memiliki efek moderasi pada hubungan antara $\mathrm{RR}$ terhadap $\mathrm{h}$ a $\mathrm{r} \mathrm{g}$ a saham

$\mathrm{H}_{6 \mathrm{c}}$ : Interest rate memiliki efek moderasi pada hubungan antara EPS terhadap harga saham

$\mathrm{H}_{6 \mathrm{~d}}$ : Interest rate memiliki efek moderasi pada hubungan antara ROE terhadap $\mathrm{h}$ a $\mathrm{r} g$ a saham

$\mathrm{H}_{6 \mathrm{e}}$ : Interest rate memiliki efek moderasi pada hubungan antara PAT terhadap $\mathrm{h}$ a $\mathrm{r} \mathrm{g}$ a saham

Pengaruh Political Connection (PC) sebagai variabel moderator terhadap Harga Saham

Berdasarkan penelitian yang telah dilakukan oleh Rusmin et al (2012), terdapat pengaruh yang positif antara political connection dengan kinerja perusahaan yang diukur dengan EPS. Menurut Ang et al (2011) ada hubungan positif antara perusahaan yang memiliki hubungan politik dengan nilai perusahaan bersangkutan. Hasil tersebut sejalan dengan penelitian yang dilakukan oleh Do et al 
(2009) yang memperoleh hasil political connection memberikan pengaruh yang positif pada nilai perusahaan. Dengan demikian dapat ditarik umusan hipotesis untuk hubungan antara political connection dengan harga saham yaitu:

$\mathrm{H}_{7 \mathrm{a}}$ : Political connection memiliki efek moderasi pada hubungan antara dividen terhadap harga saham

$\mathrm{H}_{7 \mathrm{~b}}$ : Political connection memiliki efek moderasi pada hubungan antara RR terhadap harga saham

$\mathrm{H}_{7 \mathrm{c}}$ : Political connection memiliki efek moderasi pada hubungan EPS terhadap $\mathrm{h}$ a $\mathrm{r} g$ a saham

$\mathrm{H}_{7 \mathrm{~d}}$ : Political connection memiliki efek moderasi pada hubungan antara ROE terhadap harga saham

$\mathrm{H}_{7 \mathrm{e}}$ : Political connection memiliki efek moderasi pada hubungan antara PAT terhadap harga saham

\section{METODE}

Objek penelitian yang digunakan dalam penelitian ini adalah perusahaan yang terdaftar $\mathrm{di}$ BEI periode 2012 sampai tahun 2016 yang memenuhi kriteria. Dengan menggunakan metode purposive sampling dalam teknik pengambilan sampel, diperoleh 63 perusahaan yang memenuhi kriteria untuk dijadikan sebagai sampel. Perusahaan tersebut antara lain 1 perusahan dari sektor aneka industri, 12 perusahaan dari industri barang konsumsi, 6 perusahaan dari industri dasar dan kimia, 1 perusahaan dari industri infrastruktur, utilitas dan transportasi, 13 perusahaan dari industri keuangan, 14 perusahaan dari industri perdagangan, jasa dan investasi, 1 perusahaan dari industri pertambangan, 1 perusahaan dari industri pertanian dan 14 perusahaan dari industri property, real estate dan konstruksi bangunan. Namun setelah dilakukan pengolahan data terdapat outlier. Sehingga total observasi yang dilakukan dalam penelitian ini pada model 1 yang awalnya 63 perusahaan $\times 5$ tahun $=$ 315 data observasi dikurangi data yang outlier menjadi 242 data observasi.

Pada tabel 1 berikut ditampilkan proses pengambilan sampel yang dilakukan pada penelitian ini setelah menetapkan beberapa kriteria tertentu:

Tabel 1. Pengambilan Sampel Perusahaan dengan Metode Purposive Sampling

\begin{tabular}{lcc}
\hline \multicolumn{1}{c}{ Deskripsi Kriteria } & $\begin{array}{c}\text { Jumlah } \\
\text { Perusahaan }\end{array}$ & Jumlah Data \\
\hline $\begin{array}{l}\text { Perusahaan yang konsisten terdaftar pada Bursa Efek Indonesia (BEI) dari } \\
\text { tahun 2012 sampai dengan tahun 2016 }\end{array}$ & 427 & 2135 \\
\hline Perusahaan yang laporan keuangannya tidak dalam mata uang rupiah & 39 & $(195)$ \\
\hline Laporan keuangan tidak berakhir pada tanggal 31 Desember & 24 & $(120)$ \\
\hline $\begin{array}{l}\text { Perusahaan tidak memperoleh laba positif yang konsisten tahun 2012 sampai } \\
\text { dengan tahun 2016 }\end{array}$ & 291 & $(1455)$ \\
\hline $\begin{array}{l}\text { Perusahaan tidak membayarkan dividen secara konsisten dari tahun 2012 } \\
\text { sampai dengan tahun 2016 } \\
\text { Total data sampel yang digunakan dalam penelitian }\end{array}$ & 10 & $(50)$ \\
\hline Outlier = 73 data & 63 & 315 \\
\hline
\end{tabular}

Sumber: Hasil Penelitian

Tabel 2. Definisi Variabel Operasional

\begin{tabular}{|c|c|c|c|c|}
\hline $\begin{array}{c}\text { Tipe } \\
\text { Variabel }\end{array}$ & Variabel & Pengukuran & Deskripsi Variabel & $\begin{array}{c}\text { Sumber } \\
\text { Referensi }\end{array}$ \\
\hline Dependen & Harga Saham & Closing Price & $\begin{array}{l}\text { Harga saham penutupan pada } \\
\text { akhir tahun }\end{array}$ & Deitiana (2011) \\
\hline \multirow{4}{*}{ Independen } & Dividen & $\begin{array}{l}\text { Dividend per share } \\
\text { (DPS) }\end{array}$ & $\begin{array}{l}\text { Dividen dibagi jumlah saham } \\
\text { beredar }\end{array}$ & Majanga (2015) \\
\hline & $\begin{array}{l}\text { Retention } \\
\text { Ratio }\end{array}$ & $\mathrm{RR}$ & $\begin{array}{c}\text { (Net Income-Dividend) dibagi Net } \\
\text { Income }\end{array}$ & Ali et al (2015) \\
\hline & $\begin{array}{l}\text { Earnings per } \\
\text { Share }\end{array}$ & EPS & $\begin{array}{l}\text { Net Income dibagi jumlah saham } \\
\text { beredar }\end{array}$ & $\begin{array}{l}\text { Margaretha F } \\
(2014)\end{array}$ \\
\hline & $R O E$ & ROE & $\begin{array}{l}\text { Profit After Tax dibagi } \\
\text { Shareholders Equity }\end{array}$ & $\begin{array}{c}\text { Bilal dan Jamil } \\
(2015)\end{array}$ \\
\hline
\end{tabular}


Lanjutan Tabel 2. Definisi Variabel Operasional

\begin{tabular}{ccccc}
\hline Independen & $\begin{array}{c}\text { Profit After } \\
\text { Tax }\end{array}$ & PAT & $\begin{array}{c}\text { Laba perusahaan setelah dikurangi } \\
\text { beban operasional, bunga dan } \\
\text { pajak }\end{array}$ & $\begin{array}{c}\text { Hunjra et al } \\
(2014)\end{array}$ \\
\hline \multirow{3}{*}{ Moderator } & Interest Rate & IR & Interest Rate dari data BI & Khan (2014) \\
\cline { 2 - 5 } & $\begin{array}{c}\text { Political } \\
\text { Connection }\end{array}$ & PC & $\begin{array}{c}\text { Proporsi jajaran BOD yang } \\
\text { bekerja dibawah birokrat } \\
\text { pemerintah dibagi total BOD }\end{array}$ & Lin (2016) \\
\hline
\end{tabular}

\section{Analisis Regresi}

Persamaan linear regresi berganda untuk penelitian ini model berikut:

$\mathrm{CP}_{\mathrm{t}}=\mathrm{a} 0+\beta_{1} \mathrm{DPS}_{\mathrm{t}}+\beta_{2} \mathrm{RR}_{\mathrm{t}}+\beta_{3} \mathrm{EPS}_{\mathrm{t}}+\beta_{4} \mathrm{ROE}_{\mathrm{t}}+\beta_{5} \mathrm{PAT}_{\mathrm{t}}+\beta_{6} \mathrm{DPS}_{\mathrm{t}} \mathrm{IR}_{\mathrm{t}}+\beta_{7} \mathrm{RR}_{\mathrm{t}} \mathrm{IR}_{\mathrm{t}}+\beta_{8} \mathrm{EPS}_{\mathrm{t}} \mathrm{IR}_{\mathrm{t}}+\beta_{9} \mathrm{ROE}_{\mathrm{t}} \mathrm{IR}_{\mathrm{t}}$

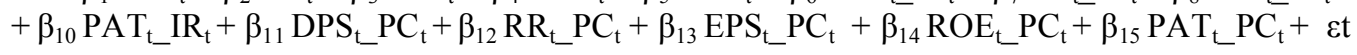

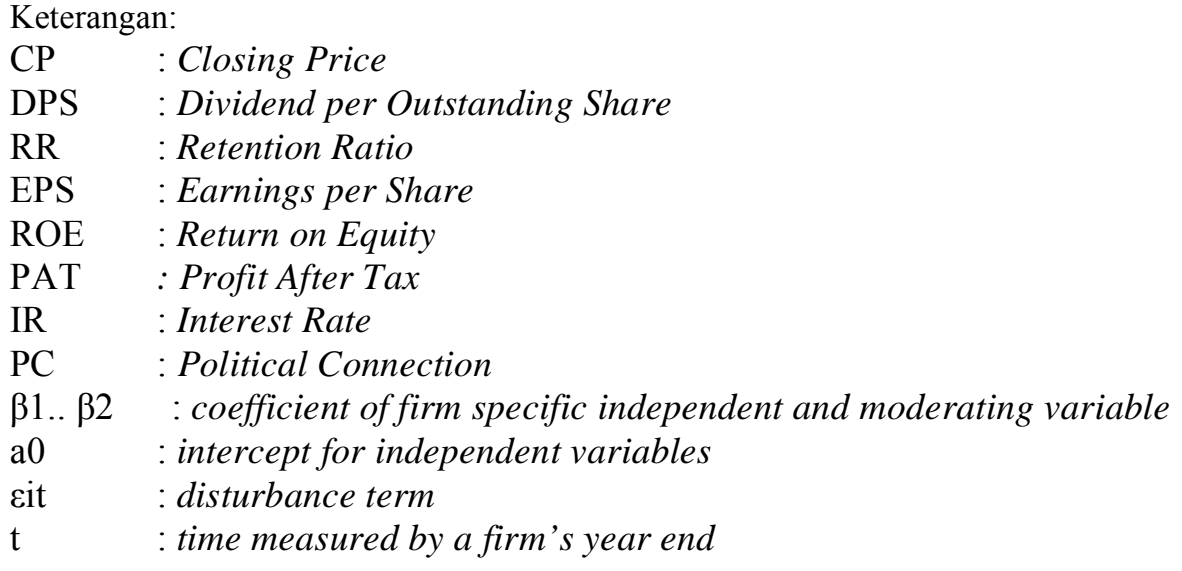

\section{HASIL PENELITIAN}

Hasil penelitian yang bisa dilihat pada tabel 3 maka diketahui bahwa dividen memiliki pengaruh negatif terhadap harga saham dilihat dari nilai signifikansi $=0,000<0,05$ dan koefisien nya $-12,733$. Hal ini berarti dengan meningkatnya dividen maka harga saham akan menurun. Banyak investor yang ingin membeli saham perusahaan tersebut karena tertarik akan kemampuan perusahaan dalam menghasilkan laba yang tinggi dengan asumsi makin tinggi laba yang ditahan artinya pembagian dividen yang kecil ataupun rendah akan tetap meningkatkan harga saham perusahaan teresebut. Hasil penelitian ini sejalan dengan penelitian yang dilakukan oleh Wasfi Al Troudi dan Milhem (2013) yang menyatakan bahwa dividen mempengaruhi harga saham.

$\mathrm{H}_{1}$ : Terdapat pengaruh dividen terhadap harga saham

Hasil penelitian yang bisa dilihat pada tabel 3, dapat disimpulkan bahwa RR memiliki pengaruh terhadap harga saham karena nilai signifikansinya $0,000>0,05$. Dengan demikian dapat dikatakan bahwa semakin rendah RR maka harga saham akan semakin tinggi. Penelitian ini sejalan dengan penelitian Iqbal et al (2014) yang memiliki hasil bahwa RR berpengaruh terhadap harga saham $\mathrm{H}_{2}$ : Terdapat pengaruh retention ratio $(\mathrm{RR})$ terhadap harga saham

Hasil penelitian yang bisa dilihat pada tabel 3 menunjukkan bahwa nilai signifikansi EPS adalah 0,000 dimana lebih kecil dari 0,05 dan koefisiennya sebesar 2,070 yang berarti EPS berpengaruh secara positif terhadap harga saham. Hal ini berarti senakin tinggi EPS maka harga saham akan semakin tinggi. Oleh karena itu baik calon investor ataupun investor saat ini biasanya tertarik dengan angka EPS yang dilaporkan perusahaan. Permintaan akan saham di pasaran akan meningkat dan dengan begitu harga saham perusahaan juga akan ikut meningkat di masa depan. Hasil penelitian ini sejalan dengan penelitian yang dilakukan oleh Zhang et al (2017) dan Shah dan Noreen (2016) yang menyatakan bahwa earnings per share berpengaruh terhadap harga saham.

$\mathrm{H}_{3}$ : Terdapat pengaruh earnings per share (EPS)

terhadap harga saham

Hasil penelitian yang bisa dilihat pada tabel 3 dapat disimpulkan bahwa ROE berpengaruh positif terhadap harga saham dengan nilai signifikansi 0,000 $<0,05$ dan koefisiennya sebesar 0,611 yang berarti 
ROE berpengaruh secara positif terhadap harga saham. Investor menilai angka ROE sebagai jumlah profit yang mampu dihasilkan dari setiap rupiah modal yang telah diinvestasikan pada sebuah perusahaan. Apabila nilai ROE tinggi maka akan menggambarkan kinerja yang baik pada manajemen sebuah perusahaan dalam menaikkan pendapatannya menggunakan modal yang dimilikinya. Hal ini akan membuat investor merasa yakin untuk menanamkan modalnya melalui pembelian saham perusahaan karena investor tersebut akan menerima imbal hasil dan tentunya akan mempengaruhi harga saham perusahaan bersangkutan dipasaran. Hasil penelitian ini sejalan dengan penelitian yang dilakukan oleh Nurhayati (2013) dan Trisnawati (2011) yang menyatakan bahwa ROE berpengaruh terhadap harga saham.

$\mathrm{H}_{4}$ : Terdapat pengaruh return on equity (ROE) terhadap harga saham

Hasil penelitian yang dapat dilihat pada tabel 3, nilai signifikansi PAT adalah 0,000 dimana lebih kecil dari 0,005 dan dengan nilai koefisiennya sebesar 0,179 yang berarti PAT memiliki pengaruh positif terhadap harga saham. Hal ini mengindikasikan apabila perusahaan mampu memanfaatkan dana dari pemegang saham yang tersedia dan memberikan imbal hasil yang lebih baik atas investasi tersebut maka hal ini akan berdampak baik pula pada nilai sahamnya. Banyak investor yang ingin membeli saham perusahaan tersebut karena tertarik akan kemampuan perusahaan dalam menghasilkan laba yang tinggi dengan asumsi semakin tinggi laba yang dihasilkan maka semakin besar pembayaran dividen yang akan dilakukan perusahaan tersebut. Hasil penelitian ini sejalan dengan penelitian yang dilakukan oleh Uddin (2009) dan Khan (2012) yang menyatakan bahwa PAT berpengaruh terhadap harga saham.

$\mathrm{H}_{5}$ : Terdapat pengaruh profit after tax (PAT) terhadap harga saham
Tabel 3 dapat dilihat bahwa interest rate memiliki nilai signifikansi yang kurang dari 0,05 pada variabel dividen, RR, EPS, ROE dan PAT sehingga dapat disimpulkan bahwa interest rate memiliki efek moderasi pada seluruh variabel independen yaitu dividen, RR, EPS, ROE dan PAT. Dengan demikian dapat dikatakan bahwa tingkat suku bunga dapat mempengaruhi baik penghasilan maupun pengeluaran dari sebuah perusahaan karena tingkat suku bunga yang berlaku dipasaran menjadi faktor penentu pengambilan keputusan bagi pengelola perusahaan untuk menetapkan alokasi dana yang dimiliki perusahaan.

$\mathrm{H}_{6}$ : Terdapat efek moderasi antara variabel interest rate dengan dividen, RR, EPS, ROE dan PAT terhadap harga saham.

Tabel 3 dapat dilihat bahwa political connection memiliki efek moderasi pada beberapa variabel independen yaitu EPS dan PAT. Namun untuk variabel dividen, RR dan ROE, political connection tidak memiliki efek moderasi. Hal ini dapat disebabkan karena investor akan berasumsi apabila sebuah perusahaan dipimpin oleh orang yang memiliki hubungan politik maka akan ada kesulitan di masa depan apabila pemimpin tersebut terlibat kasus politik di luar perusahaan dan akan mengancam kondisi perusahaan bersangkutan. Hal ini akan memberi dampak kurang baik pula pada saham perusahaan di pasaran. Akan menurunnya permintaan akan saham dipasaran membuat harga saham perusahaan ini ikut menurun pula pada akhirnya.

$\mathrm{H}_{7}$ : Terdapat efek moderasi antara variabel political connection dengan EPS dan PAT terhadap harga saham namun tidak ada efek moderasi antara variabel interest rate dengan dividen, RR dan ROE terhadap harga saham.

Tabel 3. Hasil Uji Statistik t

\begin{tabular}{cccc}
\hline Variabel & Koefisien B & Signifikan & Kesimpulan \\
\hline DPS & -12.733 & 0.000 & Ho ditolak \\
\hline RR & -0.385 & 0.000 & Ho ditolak \\
\hline EPS & 2.070 & 0.000 & Ho ditolak \\
\hline ROE & 0.611 & 0.000 & Ho ditolak \\
\hline PAT & 0.179 & 0.000 & Ho ditolak \\
\hline DPS_IR & 13.498 & 0.000 & Ho ditolak \\
\hline RR_IR & 0.413 & 0.000 & Ho ditolak \\
\hline EPS_IR & -2.284 & 0.000 & Ho ditolak \\
\hline ROE_IR & -0.584 & 0.000 & Ho ditolak \\
\hline PAT_IR & -0.109 & 0.001 & Ho ditolak
\end{tabular}


Lanjutan Tabel 3. Hasil Uji Statistik t

\begin{tabular}{cccc}
\hline Variabel & Koefisien B & Significance & Kesimpulan \\
\hline DPS_PC & -0.001 & 0.945 & Ho diterima \\
\hline RR_PC & -0.024 & 0.059 & Ho ditolak \\
\hline EPS_PC & 0.052 & 0.000 & Ho ditolak \\
\hline ROE_PC & 0.002 & 0.881 & Ho diterima \\
\hline PAT_PC & -0.018 & 0.004 & Ho ditolak
\end{tabular}

Dependent: Closing Price

Sumber: Hasil Pengolahan Data SPSS

\section{SIMPULAN DAN SARAN}

Setelah melakukan penelitian dan pembahasan tentang dividen, retention ratio (RR), earnings per share (EPS), return on equity (ROE), profit after tax (PAT), interest rate (IR) dan political connection (PC) terhadap harga saham, maka kesimpulan yang diperoleh adalah sebagai berikut:

1) Dividen berpengaruh secara negatif terhadap harga saham; 2) Retention ratio (RR) berpengaruh secara negatif terhadap harga saham; 3) Earnings per share (EPS) berpengaruh secara positif terhadap harga saham; 4) Return on equity (ROE) berpengaruh secara positif terhadap harga saham; 5) Profit after tax (PAT) berpengaruh secara positif terhadap harga saham; 6) Interest rate (IR) memiliki efek moderasi dengan variabel dividen, RR, EPS, ROE dan PAT terhadap harga saham; 7) Political connection (PC) memiliki efek moderasi dengan variabel EPS dan PAT namun tidak memiliki efek moderasi dengan variabel dividen, $\mathrm{RR}$ dan ROE terhadap harga saham.

Berdasarkan kesimpulan yang telah diuraikan di atas, maka hasil penelitian ini diharapkan dapat memberikan manfaat bagi beberapa pihak sebagai contoh:

1) Bagi para investor dalam memutuskan keputusan berinvestasi sebaiknya tidak hanya fokus pada dividen yang dibayarkan oleh sebuah perusahaan akan tetapi sebaiknya memperhatikan faktor lainnya seperti nilai ROE dan EPS nya yang menggambarkan seberapa banyak tingkat pengembalian yang diperoleh investor dalam menanamkan modalnya pada sebuah perusahaan; 2) Bagi pada manajer yang sebaiknya menurunkan tingkat dividen yang dibayarkan jika memberikan hasil atau pengaruh yang negatif terhadap harga saham. Manajer bisa saja menggunakan laba yang diperolehnya tidak hanya untuk membayarkan dividen tetapi juga untuk melakukan investasi lain yang dapat memberikan hasil pada meningkatnya nilai perusahaan misalnya pembelian aset yang berpotensi dapat meningkatkan produksi perusahaan yang pada akhirnya berdampak positif pada laba dan harga saham perusahaan dipasaran. Pihak pengelola perusahaan juga diharapkan dapat meningkatkan laba setelah pajak karena dari hasil penelitian diperoleh bahwa PAT mempengaruhi harga saham secara positif. Selain itu, besar kecilnya nilai EPS juga dapat mempengaruhi harga saham apabila dilihat dari hasil penelitian yang menunjukkan EPS berpengaruh positif terhadap harga saham.

\section{DAFTAR PUSTAKA}

Adesola, W. A. and Okwong. (2009). An Empirical Study of Dividend Policy of Quoted Companies in Nigeria. Global Journal of Social Science Vol. 8, No. 1, 85101.

Afzal, A. dan Rohman, A. (2012). Pengaruh Keputusan Investasi, Keputusan Pendanaan dan Kebiakan Dividen terhadap Nilai Perusahaan. Diponegoro Journal of Accounting Vol. 1, No. 2, 1-9.

Al Masum, A. (2014). Dividend Policy and Its Impact on Stock Price-A Study on Commercial Banks Listed in Dhaka Stock Exchange. Global Disclosure of Economics and Business Vol. 3, No.1, 9-17.

Ali Adnan, Ali J. F., and Sharif Ilyas. (2015). Effect of Dividend Policy on Stock Prices. Business and Management Studies: An International Journal Vol. 3, No.1, 56-87.

Ali, Hamdan. (2014). Impact of Interest Rate on Stock Market; Evidence from Pakistani Market. IOSR Journal of Business and Management Vol. 16, No.1, 64-69.

Ang, J. S., Ding, D. K., and Thong, T. Y. (2011). Political Connection and Firm Value. Asian Development Review Vol. 30, No. 2, 131-166.

Asif Muhammad, Arif Kashif and Akbar Waqar. (2016). Impact of Accounting Information on Share Price: Empirical Evidence from Pakistan Stock Exchange. International Finance and Banking Vol. 3, No. 1, 124-135.

Atmojo B. T., Arifati Rina dan Abrar. (2016). Pengaruh Rasio Profotabilitas, DPS, EPS, dan ROE terhadap Harga Saham Perusahaan Manufaktur. Journal of Accounting Vol. 2, No. 2, Maret, 1-21. 
Azhagaiah, R. and Priya, N. S. (2008). The Impact of Dividend Policy on Shareholders' Wealth. International Research Journal of Finance and Economics Vol. 20, 181-187.

Baker R. E., Christensen T. E., and Cottrell David M. (2014). Advanced Financial Accounting. 10th Ed. New York: The McGraw-Hill Companies, Inc.

Barakat, M. R., Elgazzar, S. H., and Hanafy, K. M. (2016). Impact of Macroeconomics Variables on Stock Markets: Evidence from Emerging Markets. International Journal of Economics and Finance Vol. 8, No. 1, 195-207.

Bilal, Z. O., and Jamil, S. A. (2015). Does Dividend Policy Impact Stock Market Prices? - Evidence From Oman. IJABER Vol. 13, No. 9, 6873-6883.

Brigham, E. F., and Joel F. H. (2011). Fundamentals of Financial Management. 12th Ed. United States: South Western.

De Wet J. and Mpinda Mvita. (2013). The Impact of Dividend Payments On Shareholders' Wealth: Evidence From The Vector Error Correction Model. International Business and Economics Research Journal Vol. 12, No. 11, 1451-1466.

Deitiana, Tita. (2011). Pengaruh Rasio Keuangan, Pertumbuhan Penjualan dan Dividen terhadap Harga Saham. Jurnal Bisnis dan Akuntansi Vol. 13, No. 1, April, 57-66.

Dewi Rachmawati dan Wahyudi Sugeng. (2012). Analisis Pengaruh Rasio Keuangan dan Makro Ekonomi terhadap Harga Saham pada Perusahaan LQ 45 yang terdaftar di BEI tahun 2007-2011. Diponegoro Journal of Management Vol. 1, No. 1,1-11.

Do, A. Q., Lee T. B., and Nguyen, B. D. (2009). Political Connections and Firm Value: Evidence from the Regression Discontinuity Design of Close Gubernatorial Elections. Review of Financial Studies. Vol. 22, No. 6, 1-29.

Faccio Mara. (2006). Politically Connected Firms. The American Economic Review Vol. 96, No. 1, 369-386.

Gitman, L. J. and Chad J. Z. (2015). Principles of Managerial Finance. 14th Ed. England: Pearson Education Limited.

Hunjra, A. I., Shahzad Muhammad and Chani, M. I. (2014). Impact of Dividend Policy, EPS, ROE, Profit After Tax on Stock Prices. International Journal of Economics and Empirical Research Vol. 2, No. 3, $109-115$.

Iftikhar, A. B., Raja, N. U., and Sehran, K. N. (2017). Impact of Dividend on Stock Prices of Firm. International Scientific Journal Vol. 47, No. 3, 32-37.

Iqbal Arslan, Ahmed Farooq and Shafi, A. R. (2014). The Effect of Dividend Bubble on Share Price: Evidence from KSE-30 Index. Research Journal of Finance and Accounting Vol. 5, No. 12, 83-87.

Jo, H., and Pan, C. (2009). Why are Firms with Entrenched Managers More Likely to Pay Dividends? Review of Accounting and Finance. Vol. 8, No. 1, 87-116.
Kesto, D. A., and Ravi J. (2015). Determinants of Dividend Payout: A Case of Banking Sector in Ethiopia. Journal of Business Management Vol. 1, No. 5, 51-56.

Khan, K. I. (2012). Effect of Dividends on Stock Prices - A case of Chemical and Pharmaceutical Industry of Pakistan. Management Vol.2, No. 5, 141-148.

Khan, M. S. (2014). Macroeconomics Variables and Its Impact on KSE-100 Index. Universal Journal of Accounting and Finance Vol. 2, No. 2, 33-39.

Kumaresan, Sinthuja. (2014). Impact of Dividend Policy on Share Holders Wealth. International Journal of Technological Exploration and Learning Vol. 3, No.1,349-352.

Lin, T. J. (2016). The Relationship Between Political Connections, Information Asymetry and The Value of Cash Holdings - Evidence from China. Journal of Accounting, Finance and Management Strategy Vol. 11, No. 2, 67-94.

Majanga, B. B. (2015). The Dividend Effect on Stock Price An Empirical Analysis of Malawi Listed Company. Accounting and Finance Research Vol. 4, No. 3, 99105 .

Margaretha Farah. (2014). Dasar - Dasar Manajemen Keuangan. Jakarta: Dian Rakyat.

Marlina Lisa dan Clara Danica. (2009). Analisis Pengaruh Cash Position, Debt to Equity Ratio dan Return On Assets terhadap Dividend Payout Ratio. Jurnal Manajemen Bisnis Vol. 2, No. 1. 1-6.

Matthew, M. O., Chinedu, E. and Mike A. (2014). Effect of Dividend Payment on the Market Price of Shares: A Study of Quoted Firms in Nigeria. Journal of Economics and Finance Vol. 5, No. 4, 49-62.

Mudlofir, A. dan Supriyanto (2016). Pengaruh ROA, ROE, EPS, Inflasi, DER dan Inventory Turnover terhadap Harga Saham pada Perusahaan Otomotif yang terdaftar di BEI. Journal of Accounting Vol. 2, No. 2, Maret, 1-47.

Nurhayati, M. (2013). Profitabilitas, Likuiditas dan Ukuran Perusahaan Pengaruhnya terhadap Kebijakan Dividen dan Nilai Perusahaan Sektor Non Jasa. Jurnal Keuangan dan Bisnis Vol. 5, No.2, 144-153.

Rusmin, R., Evans, J. and Hossain, M. (2012). Ownership Structure, Pollitical Connections and Firm Performance: Evidence from Indonesia. Corporate Ownership and Control Vol. 10, No. 1, 434-443.

Sadaf, R. (2013). Impact of Macroeconomic Variables on Stock Returns of Chemical Industry in Pakistan. NUML Journal of Management and Technology Vol. 8, No. 1, 31-43.

Sekaran, U. and Roger, B. (2012). Research Methods for Business. 6th Ed. United Kingdom: John Wiley \& Sons Ltd.

Shah, A. S. and Noreen, U. (2016). Stock Price Volatily and Role of Dividend Policy: Empirical Evidence from Pakistan. International Journal of Economics and Financial Issues Vol. 6, No. 2, 461-472. 
Sharif, T., Purohit, H. and Pillai, R. (2015). Analysis of Factors Affecting Share Prices: The Case of Bahrain Stock Exchange. International Journal of Economics and Finance Vol. 7, No. 3, 207-216.

Trisnawati, F. (2011). Pengaruh Peristiwa Politik Terhadap Perubahan Harga Saham. Pekbis Jurnal Vol.3, No.3, 528-535.

Uddin, G. S. (2009). Relationship between Interest Rate and Stock Price: Empirical Evidence from Developed and Developing Countries. International Journal of Business and Management Vol. 4, No. 3, 43-51.

Wasfi Al Troudi and Milhem, M. (2012). Cash Dividend, Retained Earnings andStock Prices: Evidence from Jordan. Interdiscplinary Journal of Contemporary Research Business Vol. 4, No. 12, 585-599.
Weygandt, J. J., Kieso, D. E., and Kimmel, P. D. (2014). Financial Accounting. 9th Ed. New York: John Wiley \& Sons, Inc.

Wulandari, T. dan Raharja. (2013). Analisis Pengaruh Political Connection dan Struktur Kepemilikan terhadap Kinerja Perusahaan. Diponegoro Journal of Accounting Vol. 2, No. 1, 1-12.

Zhang, C., Lv, Y. and Guo, Q. (2017). Political Connections of Independent Directors and Firm Performance: Evidence of Chinese listed Manufacturing Companies Over 2008-2013. Management and Humanities Science Vol.3, 69-73. 